
\title{
25 Research Soure \\ Factors Related to Information and Communication Technologies Adoption in Small Businesses in Colombia
}

Julian Duran ( $\sim$ julduranp@gmail.com )

Universidad Santiago de Cali https://orcid.org/0000-0002-8252-729X

Rubén Castillo

Universidad Santiago de Cali

\section{Research}

Keywords: Technology adoption, information and communication technology, small businesses, business behavior

Posted Date: August 9th, 2021

DOI: https://doi.org/10.21203/rs.3.rs-757561/v1

License: (c) (i) This work is licensed under a Creative Commons Attribution 4.0 International License.

Read Full License 


\section{Abstract}

This study is an analysis of how a set of factors influenced the decision to adopt information and communication technologies (ICTs) in small businesses in Colombia; for this purpose, a logistic modeling is applied wherein the explained variable represents the companies' decision to adopt ICTs. The main explanatory elements include the demographic aspects of the owner, the company characteristics, and the legal practice of the company and its social capital. Data from the Microbusiness Survey 2019 conducted by the National Administrative Department of Statistics of Colombia were employed. The study results noted that personal aspects such as the age and gender of the owner have an impact on the adoption of ICTs. Moreover, computer equipment is critical in these small businesses, thereby making a policy of subsidizing the acquisition of these devices relevant. In addition, business formality and social capital ties have a positive influence on the use of ICTs.

\section{Introduction}

In today's techno-economic world, information and communications technologies (ICTs) are generally regarded as a crucial tool to improve the competitiveness of the economy at micro and macroeconomic levels. The consensus in the extant literature is that ICTs have a significant influence on company productivity, but this influence will depend on the extent to which they are disseminated and widely used to their optimal level. For this reason, understanding the determinants of adopting these technologies is a progressive line of research with significant contributions in recent years.

According to the Organization for Economic Co-operation and Development (2000), in times of intensified competition and economic crisis, ways in which ICT contribute to innovation and growth should be studied, and hence, in recent years, there has been an increased interest in measuring their impact on different economies. These research efforts based on ICT influence on business performance and their importance as a key driver of business growth have been extensively examined using both a growth accounting and business growth approach.

Recent research in this area has produced evidence that the observed contribution of computerization is accompanied by relatively large and slow (taking years to implement) investments in complementary inputs, such as organizational capital, which may be omitted from conventional productivity calculations.

As competition has intensified over the past two decades, companies have found it necessary to restructure and improve their practices to find new and more efficient ways of gaining competitive advantages to survive. In this context, ICTs offer benefits for a wide range of business processes and improve information and knowledge management within the company, thus leading to better yields and more productivity. Evidence at company level suggests that rather than being unproductive, computers have made a greater contribution to business productivity with respect to the investment in other physical assets, along with the projection that they are going to increase even more in the future. 
Along these lines, many authors have discussed the black box of technology and its influence on the production of the economy (e.g., Brynjolfsson \& Hitt, 2000).

This study analyzes a set of factors associated with the adoption of ICTs in small businesses in Colombia and thus makes progress in subsequent studies in view of their impact on small businesses in this country. Therefore, a logistic model is used in which the variable to be explained is the decision to adopt ICTs, which is binary (to adopt or not to adopt). As explanatory variables, a group of factors is approached that represent the demographic characteristics of the owner, the characteristics of the company, legal practice, social capital, the sectoral adoption rate, and the economic environment in which the business operates.

The study is intended to highlight the aspects that are really influencing the adoption of ICTs by small businesses in developing countries, as it is common to analyze the technological adoption in large companies or in developed economies. The use of these new technologies in a context such as Colombia has been slow in relation to the technological infrastructure available for the development of telework. For example, Valdés, Castillo, and Duran (2019) mentioned that the number of Internet subscribers increased from 3.3 million in 2010 to 16.9 million in 2017, while the Internet penetration rate increased from $7.3-32.5 \%$ in the same period, and the national Internet subscriber penetration rate was $32.8 \%$. Such indicators, particularly the penetration rate, show that there is still a long way to go and that the current infrastructure endowment, as a general-purpose technology, is a constraint for the adoption of ICT at all levels. In addition, companies resist change and prefer to keep old productive schemes. Therefore, this study aims at providing a framework of evidence on what aspects are related to a greater acceptance of ICT use, and as a consequence, it suggests policy lines in the direction indicated by the results.

The remainder of the paper is organized in the following manner. Section 2 presents the main background and theoretical framework. Section 3 presents the methodology employed, describing the database and the empirical model used. Section 4 states the results and discussion. Section 5 mentions the conclusions.

\section{Background And Theoretical Framework}

The adoption of technologies in the framework of technology, economy, and society studies is linked with the concept of diffusion as a fundamental process to ensure their interaction with economic growth. For this to occur, it is necessary for companies to be able to absorb and successfully apply new technologies. Thus, it is essential to identify the determinants of this adoption and diffusion both from the research and technological development policy options viewpoints.

Within the approaches of technological adoption, it is established that this is more of a social process that includes technical-social entities that shape the adoption behavior involving multilayered situations or contexts including structural arrangements, culture, division of labor, specialization, standardization, operating procedures, communication patterns, ideologies, government regulations, competitive forces, supplier strategies and knowledge about technology, and socioeconomic conditions, (Chen \& Chang, 
2013; Venkatesh et al., 2003; Orlikowski, 1992; Jacobsson \& Linderoth, 2010; Rogers, 1995). In relation to the role of the business environment, Jacobsson and Linderoth, (2010) stated that it can affect both the adoption and implementation of new ICT applications and the existing power relations in the organizations.

In this study, we intend to move toward a theoretical-empirical framework that allows us to analyze some of the factors that affect the decision to adopt ICT, especially in small companies, and given the data limitations that do not allow us to have a wider range of elements to consider. In this context, the aspects to consider and whose influence is to be compared in the adoption process are demographic characteristics of the owner or manager (gender and age), characteristics of the company (age, size, and computer equipment), legal practices of the company (formality), social capital (associativity and cooperative affiliation), and the diffusion or epidemic effect of ICT (Figure 1). The analysis of the variables and their influence is explained below.

\subsection{Demographic Characteristics of the Owner}

Some studies have concluded that the demographic characteristics of the owner or manager of a company affect the adoption of technologies, either directly or indirectly (Peltier, Zhao \& Schibrowsky, 2012; Abdullah, Shamsuddin, Wahab \& Hamid, 2012; Naicker \& Van Der Merwe, 2018; Chuang, Nakatani \& Zhou, 2009). In the case of age, the willingness to adopt would be inversely correlated, i.e., young owners/managers show more openness toward the application of new knowledge and technologies, and in relation to gender, some studies suggest that men would have a greater interest in analyzing and adopting ICTs, while women, given their reluctance to be trained in computer skills, seem to be less willing to adopt these technologies (Harrison \& Rainer, 1992; llie, Slyke, Green \& Lou, 2005).

\subsection{Company Characteristics}

\section{Age}

Although there is no consensus about its impact on adoption, it should be highlighted that most of the studies are in favor of a positive effect on this decision. Thus, greater productive experience reflected in company durability would have an impact on embracing ICTs because companies would have a better vision of the need and advantages offered by new technologies, as opposed to the uncertainty or disinterest that younger companies may show (Viollaz, 2018; Khalifa, 2016; Youssef, Hadhri \& M'Henni, 2011; Meyer, 2011; Dunne, 1994).

\section{Size}

Giuri, Torrisi, and Zinovyeva (2008) confirmed that the level of ICT investments, the total amount, and the amount per employee increase with the size of the company; moreover, large companies have a higher proportion of telecommunications investments. The four following reasons explain this positive relationship: First, large companies have a greater capacity to own the benefits of adoption. Second, large and more profitable companies will also have easier access to the financial resources needed to purchase 
and install new technology. Third, large companies have the necessary skills and other resources to introduce and use new technologies. Fourth, as suggested by Khalifa (2016), large companies can quickly capture economies of scale of production through the learning curve and can spread the other fixed costs associated with adoption in number of units. For example, studies such as those of Loukis, Arvanitis, and Kyriakou (2017); Youssef, Hadhri, and M'Henni (2011); and Galliano and Roux (2008) reveal the positive effects of the age of the company in the adoption of technologies.

\section{Computer Equipment}

This factor refers to the amount of ICT-related equipment that the company has for its production, administration, and business management activities. It is related to the number of devices, but it is also very intricately linked to the sophistication of the ICT infrastructure because the effect on adoption is expected to be positive. In this regard, Loukis, Arvanitis, and Kyriakou (2017), based on the technology, organization and environment theory of Tornatzky and Fleischer (1990) and Baker (2011), conduct a study where they observed a strong relationship with positive effects between technology adoption and sophistication and the adoption of cloud computing, the latter being an indicator of ICT adoption for the glass, ceramics, and cement sectors in the European Union.

\section{3 Legal Practices}

Formalization is the process conducted by companies to join the formal economy. According to International Labour Organization (2017), the main characteristics that distinguish business formalization are being registered and licensed by national, provincial, and municipal authorities, thus having access to social security for the owner of the company and its employees, in compliance with the current legal system, including tax and labor legislation.

On the contrary, lack of formality (informality) in companies is related to the development of production and/or sales while avoiding state regulations that are deemed as a source of business inefficiency because the payment of taxes is considered to be unnecessary to achieve business goals. Moreover, the relation that there is between companies being medium sized and the presence of informality is widely known (Gómez \& Moran, 2012), as small companies are the ones that find greater difficulties in complying with the legal requirements to access formality.

Informal sector companies usually suffer from having low levels of technology, a phenomenon that has contributed to their poor development, and the causal relationship at first glance seems quite clear because the consequences are low productivity and little progress in productive and organizational terms. As the two defining characteristics of ICTs are their convergence and their speed, there is a wide range of possibilities for the collection, manipulation, transmission, storage, and presentation of information; through these possibilities a completely new way of conducting business is created. Consequently, small informal enterprises are more vulnerable to the new economic context governed by these technologies. In this regard, a study by Opiyo and K'Akumu (2006) on the assessment of the role of ICTs in the development of the informal sector in the Kariokor market cluster in Nairobi concluded that there is a 
need to prevent further marginalization of the informal sector through the use of computer and digital technologies. Along these lines, the relationship between formality and ICT adoption could be established based on business practices and culture. If companies have better legal habits, it is possible that they also develop appropriate management policies, including the monitoring and adoption of technological trends in the sector.

\subsection{Social Capital}

Social capital is understood here in the sense proposed by Coleman (1998), as the element of human capital that allows members of a given society to trust each other and cooperate in the formation of new groups and associations. The ability to form organizations depends on concepts such as property rights, contracts, and a system of commercial law. However, it also depends on a prior sense of moral community, that is, an unwritten set of rules or ethical norms that constitute the basis for social trust. Trust can dramatically reduce transaction costs, bargaining costs, and enforcement and makes possible certain efficient forms of economic organization that would otherwise be blocked by extensive rules, contracts, litigation, and bureaucracy. Moral communities, as lived and experienced by their members, tend to be the product not of rational choice in the economists' sense of the term, but of nonrational habit. Consequently, one would expect that through the bonds of trust and interaction between companies, it would be possible to transmit information about the benefits of and need to adopt certain technologies in the productive sector so that companies with greater social capital will have access to better information that would lead them to make the decision to adopt ICTs. In this sense, the work of Lee, Cho, and Hwang (2013) showed the influence of social capital in the process of tourism technology adoption, where the trust factor played an important role in the dialogue and transmission of information between managers.

\subsection{Diffusion or Epidemic Effect}

In the opinion of Helpman and Trajtenberg (1998), the adoption rate for general- purpose technologies differ across economic sectors. For example, in the case of ICT, the absorption rate and its effects on productivity are higher in information-intensive industries than in traditional low-technology sectors, thereby distinguishing the service industry from manufacturing, as the former has greater capacity to adopt new technologies. This prediction is contrasted by Haller and Siedschlag (2011) and Windrum and De Berranger (2003) who find weak or insignificant effects for the industrial sector and strong effects for knowledge-intensive industries in service activities. Moreover, at this point, it is vital to consider the effect of the general diffusion of technology on the decision to adopt ICT by individual companies. According to Rogers' (1995) model, the higher the diffusion of some technology or innovation, the higher the probability of its adoption by the marginal company, thus indicating that technology is more widely accepted by social agents.

\section{Methods}

\subsection{Data}


The empirical basis of this study is the cross-sectional data of the Microbusiness Survey 2019, conducted by the National Department of Statistics, which is the official statistics office of Colombia. This survey collects information from the smallest size companies in Colombia, with less than 10 employees; thus, it is a tool focused on capturing data from small businesses, which due to their large number and dynamics are not included in other surveys on the industry or trade conducted by the Colombian government.

Among the main issues addressed in the survey, there are aspects such as company characteristics, owner characteristics, business formality, entrepreneurship, use of ICT, social capital, and employed personnel. For the year 2019, the survey included a sample of almost 87,000 small companies from the following sectors: agriculture, manufacturing, commerce, and services. The data to be used are at the company level, and hence, it is feasible to approach a micro econometric modeling.

\subsection{Model and Variables}

To establish the factors affecting ICT adoption, a binary choice logit model was planned, where the dependent variable takes the value of 1 if the company has adopted ICTs, and 0 if it has not. As for the adoption variable, it was chosen to assume as adopters those companies that reported having access to and using the Internet, as this would imply that the business has incorporated the use of this technology in its routine activities, and with it, either to a greater or lesser degree, its multiple applications. While the independent variables refer to: the characteristics of the owner (age, gender), the characteristics of the business (age range, business formality, number of employees), equipment, social capital of the business (affiliated to associations, affiliated to a cooperative), economic environment (productive sector to which it belongs, the business is located in one of the main cities of the country) and the adoption rate of the economic sector to which it belongs. Table 1 shows the definition of each of the variables to be used and suggests the expected sign of the parameter according to the theoretical framework and literature.

The model we suggest to make the estimation and that considers the hypotheses is given below:

$$
y_{i}=\frac{1}{1+e^{-z_{i}}}+u_{i}
$$

where:

$Z_{i}=\beta_{1}+\beta_{2}$ sex $_{i}+\beta_{3}$ owner's age $_{i}+\alpha_{j} \sum_{j=1}$ business'age $_{j i}+\beta_{4}$ formality $_{i}+$ $\beta_{5}$ employees $_{i}+\beta_{6}$ amount equipment $_{i}+\beta_{7}$ associated $_{i}+$ $\beta_{7}$ cooperative affiliate $_{i}+\gamma_{k} \sum_{k=1}$ sector $_{k i}+\theta_{m} \sum_{m=1}$ city $_{m i}+$ $\beta_{8}$ sectoral adoption rate r $_{i}$

The term $u_{i}$ represents random error.

Table 1. Description of Variables. 


\begin{tabular}{|c|c|c|c|}
\hline Variable & Definition & Measure & $\begin{array}{l}\text { Expected } \\
\text { Sign }\end{array}$ \\
\hline \multirow[t]{2}{*}{ Adoption } & \multirow{2}{*}{$\begin{array}{l}\text { Dummy variable whose value is } 1 \text { if the company } \\
\text { adopts ICT }\end{array}$} & 1 = yes; & $\mathrm{N} / \mathrm{A}$ \\
\hline & & $0=$ no & \\
\hline \multirow[t]{2}{*}{ Gender } & \multirow{2}{*}{$\begin{array}{l}\text { Dummy variable whose value is } 1 \text { if the company } \\
\text { owner is male }\end{array}$} & 1 = man; & + \\
\hline & & $\begin{array}{l}0= \\
\text { woman }\end{array}$ & \\
\hline Age of Owner & Age of the company owner & $\begin{array}{l}\text { Numeric } \\
\text { Variable }\end{array}$ & - \\
\hline \multirow{2}{*}{$\begin{array}{l}1 \text { to less than } 3 \\
\text { years }\end{array}$} & \multirow{2}{*}{$\begin{array}{l}\text { Dummy variable whose value is } 1 \text { if the company is } \\
1 \text { to less than } 3 \text { years old }\end{array}$} & 1 = yes; & + \\
\hline & & $\begin{array}{l}0= \\
\text { another } \\
\text { case }\end{array}$ & \\
\hline \multirow{2}{*}{$\begin{array}{l}3 \text { to less than } 5 \\
\text { years }\end{array}$} & \multirow{2}{*}{$\begin{array}{l}\text { Dummy variable whose value is } 1 \text { if the company is } \\
3 \text { to less than } 5 \text { years old }\end{array}$} & 1 = yes; & + \\
\hline & & $\begin{array}{l}0= \\
\text { another } \\
\text { case }\end{array}$ & \\
\hline \multirow{2}{*}{$\begin{array}{l}5 \text { to less than } 10 \\
\text { years }\end{array}$} & \multirow{2}{*}{$\begin{array}{l}\text { Dummy variable whose value is } 1 \text { if the company is } \\
5 \text { to less than } 10 \text { years }\end{array}$} & 1 = yes; & + \\
\hline & & $\begin{array}{l}0= \\
\text { another } \\
\text { case }\end{array}$ & \\
\hline \multirow[t]{2}{*}{10 or more years } & \multirow{2}{*}{$\begin{array}{l}\text { Dummy variable whose value is } 1 \text { if the company is } \\
10 \text { or more years old }\end{array}$} & $1=$ yes; & + \\
\hline & & $\begin{array}{l}0= \\
\text { another } \\
\text { case }\end{array}$ & \\
\hline \multirow{2}{*}{$\begin{array}{l}\text { Company } \\
\text { Formality }\end{array}$} & \multirow{2}{*}{$\begin{array}{l}\text { Dummy variable whose value is } 1 \text { if the company is } \\
\text { formalized }\end{array}$} & $1=$ yes; & + \\
\hline & & $\begin{array}{l}0= \\
\text { another } \\
\text { case }\end{array}$ & \\
\hline No. of employees & No. of employees & $\begin{array}{l}\text { Numeric } \\
\text { Variable }\end{array}$ & + \\
\hline $\begin{array}{l}\text { No. of ICT } \\
\text { equipment }\end{array}$ & $\begin{array}{l}\text { No. of equipment, such as: PC, laptop, tablet, } \\
\text { smartphone, dataphone, etc. }\end{array}$ & $\begin{array}{l}\text { Numeric } \\
\text { Variable }\end{array}$ & + \\
\hline \multirow[t]{2}{*}{ It is associated } & \multirow{2}{*}{$\begin{array}{l}\text { Dummy variable whose value is } 1 \text { if the company is } \\
\text { associated to economic guilds }\end{array}$} & $1=$ yes; & + \\
\hline & & $0=$ no & \\
\hline \multirow[t]{2}{*}{$\begin{array}{l}\text { It is affiliate to a } \\
\text { cooperative }\end{array}$} & \multirow{2}{*}{$\begin{array}{l}\text { Dummy variable whose value is } 1 \text { if the company } \\
\text { is affiliate to a cooperative }\end{array}$} & $1=$ yes; & + \\
\hline & & $0=$ no & \\
\hline
\end{tabular}




\begin{tabular}{|c|c|c|c|}
\hline $\begin{array}{l}\text { ICT adoption rate } \\
\text { in the sector }\end{array}$ & ICT adoption rate of the sector of the company & $\begin{array}{l}\text { Numeric } \\
\text { Variable }\end{array}$ & + \\
\hline Industry & $\begin{array}{l}\text { Dummy variable whose value is } 1 \text { if the company is } \\
\text { part of the manufacturing industry }\end{array}$ & $\begin{array}{l}1=\text { yes } \\
0=\text { no }\end{array}$ & Ambiguous \\
\hline Commerce & $\begin{array}{l}\text { Dummy variable whose value is } 1 \text { if it is a } \\
\text { commerce company }\end{array}$ & $\begin{array}{l}1=\text { yes; } \\
0=\text { no }\end{array}$ & Ambiguous \\
\hline Services & $\begin{array}{l}\text { Dummy variable whose value is } 1 \text { if it is a services } \\
\text { company }\end{array}$ & $\begin{array}{l}1=\text { yes; } \\
0=\text { no }\end{array}$ & Ambiguous \\
\hline Bogota & $\begin{array}{l}\text { Dummy variable whose value is } 1 \text { if the company is } \\
\text { in Bogota }\end{array}$ & $\begin{array}{l}1=\text { yes } \\
0=\text { no }\end{array}$ & + \\
\hline Medellin & $\begin{array}{l}\text { Dummy variable whose value is } 1 \text { if the company is } \\
\text { in Medellin }\end{array}$ & $\begin{array}{l}1=\text { yes } \\
0=\text { no }\end{array}$ & + \\
\hline Cali & $\begin{array}{l}\text { Dummy variable whose value is } 1 \text { if the company is } \\
\text { in Cali }\end{array}$ & $\begin{array}{l}1=\text { yes; } \\
0=\text { no }\end{array}$ & + \\
\hline
\end{tabular}

Source: Prepared by the authors.

Table 2 shows the proportions and mean values of the variables that make up the logit model. It is important to note that the sample includes 86,969 small companies distributed in the main geographic areas and economic sectors of Colombia. For example, $45 \%$ of the companies are ICT adopters, a figure that indicates that there is still a larger proportion of businesses that do not use these technologies and provide a basis for promoting the policy of digital appropriation of ICTs. The proportion of male owners of these businesses is also higher (59\%), which reveals male dominance in the Colombian business context. The age figures of the companies show that $58.4 \%$ are 5 years old or older, so a majority of them have a certain degree of maturity. The number of companies that are formal or legalized is very low, only $13 \%$, which indicates the low effectiveness of business formality policies in the country.

The variables that represent the social capital in the companies show low proportions, only $1.7 \%$ are associated with productive associations and $1.5 \%$ are affiliated with a cooperative. In terms of economic sectors, $45.2 \%$ are in services, $31.1 \%$ in commerce, reflecting an economy where these activities predominate. Additionally, about $10 \%$ of the companies analyzed are located in the three main cities of Colombia, and the remaining $90 \%$ are in the rest of the country.

At the bottom of Table 2, are the averages of the numeric variables. The figures show that, on average, a business owner is 46.5 years old, which represents a mature age level. The number of employees per establishment is 1.4, which can be considered relatively low. The amount of equipment for ICT use per company is 0.3 , revealing little adoption of these technologies in this business segment in Colombia. 
Table 2. Average Proportions and Values of the Variables. 


\begin{tabular}{|c|c|c|}
\hline Categorical Variables & Categories & Proportion \\
\hline \multirow[t]{2}{*}{ Adoption } & Yes & $45 \%$ \\
\hline & No & $55 \%$ \\
\hline \multirow[t]{2}{*}{ Gender } & Man & $59 \%$ \\
\hline & Woman & $41 \%$ \\
\hline \multirow[t]{5}{*}{ Age of the Company } & Less than 1 year & $12.4 \%$ \\
\hline & 1 to less than 3 years & $18 \%$ \\
\hline & 3 to less than 5 years & $11.2 \%$ \\
\hline & 5 to less than 10 years & $15.4 \%$ \\
\hline & 10 years or more & $43 \%$ \\
\hline \multirow[t]{2}{*}{ Company Formality } & Yes & $13 \%$ \\
\hline & No & $87 \%$ \\
\hline \multirow[t]{2}{*}{ Associated } & Yes & $1.7 \%$ \\
\hline & No & $98.3 \%$ \\
\hline \multirow[t]{2}{*}{ Affiliated to a cooperative } & Yes & $1.5 \%$ \\
\hline & No & $98.5 \%$ \\
\hline \multirow[t]{4}{*}{ Economic Sector } & Agriculture & $11.1 \%$ \\
\hline & Industry & $12.6 \%$ \\
\hline & Commerce & $31.1 \%$ \\
\hline & Services & $45.2 \%$ \\
\hline \multirow[t]{4}{*}{ Main Cities } & Bogota & $2.8 \%$ \\
\hline & Medellin & $3.7 \%$ \\
\hline & Cali & $3.3 \%$ \\
\hline & Other Cities & $90.2 \%$ \\
\hline Numeric Variables & Mean & \\
\hline Age of the owner & 46.5 & \\
\hline No. of employees & 1.4 & \\
\hline No. of ICT equipment & 0.3 & \\
\hline
\end{tabular}




\begin{tabular}{|l|}
\hline ICT adoption rate in the sector \\
\hline No. of observations $27.3 \%$ \\
\hline
\end{tabular}

Source: Prepared by the authors.

\section{Results And Discussion}

The estimation of Equation (1) is presented in Table 3, which was calculated with robust standard errors in the coefficients to correct the presence of heteroscedasticity. Column 2 reports the coefficients and column 4 the average marginal effects associated with each explanatory factor. The results indicate that all variables were statistically significant, except for the Medellin dummy one. The impacts of the variables are consistent with the hypotheses that were proposed initially.

Firstly, gender has a negative sign, indicating that being a male owner reduces the probability of adoption, and in the fourth column the average marginal effect indicates that being male decreases the probability of adoption by $4.9 \%$. The age of the owner also has a negative sign, thus, the older they are, the lower the probability of adoption, since for each additional year the probability decreases by $0.7 \%$. Regarding the previous variables, in the research by Viollaz (2018), it is found that the age of the company administrator does not show statistical significance, and if he is male, the probability increases. This last finding is different from the result obtained here. Therefore, the result regarding gender is contrary to that suggested by previous research (Ilie, Slyke, Green \& Lou, 2005), where women would be less interested in adoption processes. While regarding the age of the owner, the finding is consistent with the idea that an older owner/manager is less likely to adopt (Abdullah, Shamsuddin, Wahab \& Hamid, 2012; Chuang, Nakatani \& Zhou, 2009).

Regarding the dichotomous variable of company age, the established ranges have a positive relationship with adoption. Note that the reference category is less than one year, thus younger companies are less prone to adopting. The positive impact of company age is consistent with the works of Meyer (2011) and Viollaz (2018), while Buenrostro and Hernandez (2019) did not show statistical significance.

The number of employees has a positive effect, thus, the greater the number of employees working in the company, the greater the willingness to embrace ICTs. This result is aligned with research by Lucchetti and Sterlacchini (2004), Galliano and Roux (2008), Battisti and Stoneman (2005), Khalifa (2016), Loukis, Arvanitis, and Kyriakou (2017) and Viollaz (2018), where it is shown that the larger the company, usually measured through the number of employees, the greater the willingness there is to adopt computer and communication technologies, and this is contrary to the work of Hollenstiein (2004) and Meyer (2011). Overall, the evidence leans toward the theory that adoption increases with company size.

Table 3. Results of the logistic model of adoption. 


\begin{tabular}{|c|c|c|c|}
\hline Independent Variables & Coefficient & Robust Standard Error & Average Marginal Effect \\
\hline Constant & $-2.003696 * \star \star$ & 0.067779 & \\
\hline Gender & $-0.265290 * \star \star$ & 0.018917 & $-0.048914 * \star \star$ \\
\hline Age of Owner & $-0.037696 * \star \star *$ & 0.000708 & 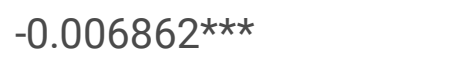 \\
\hline \multicolumn{4}{|l|}{ Age of the Company } \\
\hline 1 to less than 3 years & $0.175720 * \star \star$ & 0.032287 & 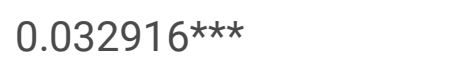 \\
\hline 3 to less than 5 years & $0.210822^{\star \star \star}$ & 0.036705 & $0.039992^{\star \star \star}$ \\
\hline 5 to less than 10 years & $0.257914 * \star \star$ & 0.257914 & $0.049099 \star \star \star$ \\
\hline 10 years or more & $0.259524 * \star \star$ & 0.031753 & $0.047692^{\star \star \star}$ \\
\hline No. of employees & $0.177178 * \star \star$ & 0.011368 & 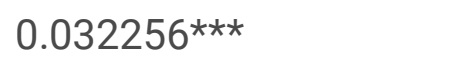 \\
\hline No. of ICT equipment & 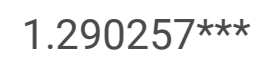 & 0.019583 & 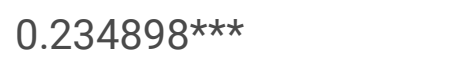 \\
\hline Company formality & $0.466023^{\star \star \star}$ & 0.028561 & $0.092121 * \star \star$ \\
\hline It is associated & $0.326954 * \star \star$ & 0.08185 & $0.064279 * \star \star$ \\
\hline $\begin{array}{l}\text { It is associated to a } \\
\text { cooperative }\end{array}$ & $0.589549 * \star \star$ & 0.081215 & 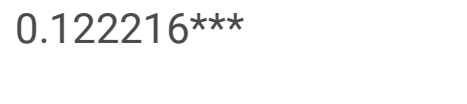 \\
\hline ICT adoption rate in the sector & $2.569144 * \star \star$ & 0.075738 & $0.467727^{\star \star \star}$ \\
\hline \multicolumn{4}{|l|}{ Economic Sectors } \\
\hline Industry & $1.392114 * \star \star$ & 0.062054 & $0.306169 * \star \star$ \\
\hline Commerce & $1.277735^{\star \star \star}$ & 0.059620 & $0.256952^{\star \star \star}$ \\
\hline Services & $1.258394 * \star \star$ & 0.059682 & $0.234201 * \star \star$ \\
\hline \multicolumn{4}{|l|}{ Main Cities } \\
\hline Bogota & $-0.131601^{\star \star}$ & 0.058064 & $-0.023178 \star \star$ \\
\hline Medellin & 0.050909 & 0.047696 & 0.009381 \\
\hline Cali & $1.068719 * \star \star$ & 0.043345 & $0.236354 * \star \star$ \\
\hline Pseudo-R ${ }^{2}$ & 26.05 & & \\
\hline No. of observations & 86,969 & & \\
\hline
\end{tabular}

Source: Prepared by the authors.

Note: ${ }^{* \star *}$ significant at $1 \%, * \star$ significant at $5 \%$. 
The amount of computer equipment owned by the establishment also shows a positive effect, and for each additional piece of equipment, the probability of adoption increases by $23.5 \%$, thus evidencing the importance of equipment provision for the use of such technology. Therefore, this is consistent with the study of Khalifa (2016), while according to Loukis, Arvanitis, and Kyriakou (2017) the positive effect is associated with the sophistication of ICT infrastructure, but the result of Buenrostro and Hernandez (2019) is ambiguous.

Business formality also makes it more likely that the decision to adopt the technology is taken, indicating that legally registered businesses also tend to use these new technologies more. In this case, the average marginal effect yields a value of $9.2 \%$. Moreover, social capital variables such as being associated and affiliated to a cooperative have a positive impact, with marginal effects of $6.4 \%$ and $12.2 \%$, respectively. Thus, associativity, in addition to strengthening trust between companies, also promotes trust in the practices developed by them, and it allegedly improves acceptance in the use of ICTs.

In addition, the company's adoption of technology is positively affected by the adoption rate of the economic sector of the business, and it may be influenced by the aggregate behavior of the sector, thus spillover effects could be seen in the diffusion of these technologies. This result is consistent with the research of Hollenstiein (2004), Galliano and Roux (2008) and Khalifa (2016), thus reinforcing the hypothesis of spillovers in the use of these technologies.

Conversely, in the dichotomous variables of the three established economic sectors positive signs are obtained, here the reference category is agriculture. Thus, belonging to the three increases adoption with respect to agricultural companies.

In addition, among the dichotomous variables for the main cities, Cali shows a positive sign while Bogota shows a negative sign. Thus, small companies in Cali tend more to adopt the technology and in Bogota less so.

\section{Conclusions}

The study shows that demographic aspects associated with the characteristics of the company's owner, which have been less addressed in the extant literature on ICT adoption, are statistically significant. For example, age has a negative impact, as does gender (male). In this case, as they are small companies depending on few people, the characteristics of the owner or manager play an important role in business policies, and hence, these factors should be considered relevant in adoption studies.

Another research finding supports the evidence that the age or longevity of the business positively affects adoption. Therefore, as companies gain maturity or experience, they see technology as a necessary tool for their sustainability. In addition, company characteristics such as size, approached through the number of workers, and the amount of ICT equipment have a positive impact on adoption. Regarding this last item, it is possible to suggest a policy to subsidize the acquisition of computer equipment, which would act as an incentive for its use. 
Moreover, business formality practices are correlated with a greater probability of using ICTs, given that operating in a formal manner would be associated with better administrative habits that recognize the need to implement new technologies. However, as shown in Table 2, only $13 \%$ of companies are formal. In this respect, business development policy should focus on raising awareness of the importance of not only having legal management practices but also of monitoring and adopting emerging technologies, which would contribute to optimize their performance.

In addition, factors associated with the company's social capital, such as membership in productive associations and cooperatives, increase the probability of technology adoption, and the bonds of trust and the sharing of information between companies generated in these networks can help them adopt the new technologies.

Finally, it would be desirable to conduct research on the use of ICTs to address other problems in small enterprises in developing countries. For example, exploring the effects of the use of these technologies on productivity, profitability, and complementarity with other aspects of business, which would highlight the impact they have on these economies.

\section{Abbreviations}

Information and communication technologies, ICTs.

\section{Declarations}

\section{Acknowledgments}

The authors are grateful for the support to the development of research by the Santiago de Cali University.

\section{Funding}

This research has been funded by the general Research Office of Universidad Santiago de Cali under call No. 01-2021.

\section{Authors' contributions}

The first author develops the methodology and results, the second author prepares the introduction and literature review. Both authors worked on the conclusions and read and approved the manuscript. Both authors participate in the general revision of the document submitted.

\section{Availability of data and materials}

All datasets are included in the manuscript.

\section{Competing interests}


The authors declare that they have no competing interests.

\section{References}

Abdullah, N.H., Shamsuddin, A., Wahab, e., \& Hamid, N.A. (2012). Preliminary qualitative findings on technology adoption of Malaysian SMEs, IEEE Colloquium on Humanities, Science and Engineering (CHUSER), 2012, pp. 15-20. https://core.ac.uk/download/pdf/12008293.pdf

Baker, J. (2011) The technology-organization-environment framework. In: Dwivedi Y, Wade M, Schneberger S (eds) Information systems theory: explaining and predicting our digital society. Springer, New York, pp 231-246.

Battisti, G., \& Stoneman, P. (2005). The Intra firm Diffusion of New Process Technologies. International Journal of Industrial Organisation, 23(1-2), 1-22.

Brynjolfsson, E., \& Hitt, L.M. (2000), Beyond Computation: Information Technology, Organizational Transformation and Business Performance. Journal of Economic Perspectives, 14(4), 23-48.

Buenrostro, H.E., \& Hernández, M. (2019). La incorporación de las TIC en las empresas. Factores de la brecha digital en las Mipymes de Aguascalientes. Economía: teoría y práctica, 50, 101-124. https://doi.org/10.24275/etypuam/ne/502019/buenrostro.

Chen, K.Y., \& Chang, M.L. (2013), User acceptance of 'near field communication' mobile phoneservice: an investigation based on the unified theory of acceptance and use of technology model. The Services Industries Journal, 33(6), 609-623.

Chuang, T., Nakatani, K., \& Zhou, D. (2009). An exploratory Study of the Extent of Information Technology Adoption in SMEs: An Application of Upper Echelon Theory. Journal of Enterprise Information Management, 22(1-2), 183-196.

Coleman, J.S. (1998). Social capital in the creation of human capital. The American Journal of Sociology, 94, S95-S120.

Dunne, T. (1994), Plant Age and Technology Use in U.S. Manufacturing Industries, Rand Journal of Economics, 25(3), 488-499.

Galliano, D., \& Roux, P. (2008). Organisational motives and spatial effects in Internet adoption and intensity of use: evidence from French industrial firms. The Annals of Regional Science, 42, 425-448. https://doi.org/10.1007/s00168-007-0157-z

Giuri, P., Torrisi, S., \& Zinovyeva, N. (2008) ICT, skills, and organizational change: evidence from Italian manufacturing firms. Industrial and Corporate Change, 17(1), 29-64. 
Gómez S., \& Moran, D. (2012). Informalidad y tributación en América Latina: Explorando los nexos para mejorar la equidad. Serie Macroeconomía del Desarrollo, 124. CEPAL, Naciones Unidas. http://hdl.handle.net/11362/5356.

Harrison, A.W., \& Rainer, R.K. (1992). The influence of individual differences on skill in end-user computing. Journal of Management Information Systems, 9(1), 93-111.

Haller, S., \& Siedschlag, I. (2011). Determinants of ICT adoption: evidence from firm-level data, Applied Economics, 43(26), 3775-3788.

Helpman, E., \& Trajtenberg, M. (1998). Diffusion of General Purpose Technologies, in Helpman, E. (ed.), General Purpose Technologies and economic, Growth, Cambridge, MA: MIT Press.

Hollenstein, H. (2004). Determinants of the adoption of Information and Communication Technologies (ICT): An empirical analysis based on firm-level data for the Swiss business sector. Structural Change and Economic Dynamics, 15(3), 315-342.

Ilie, V., Slyke, C., Green, G., \& Lou, H. (2005). Gender differences and use of communication technologies. A diffusion of innovation approach. Information Management Resource Journal, 18(3), 13-31.

Jacobsson, M., \& Linderoth, H. (2010), The influence of contextual elements, actors frames of references and technology on the adoption and use of ICT in construction projects: a Swedish case study. Construction Management and Economics, 28(1), 13-23.

Khalifa, A.B. (2016). Determinants of information and communication technologies adoption by Tunisian firms. Journal of Innovation Economics, De Boeck Université, vol. 0(2), 151-177.

Lee, B. C., Cho, J., \& Hwang, D. (2013). An integration of social capital and tourism technology adoptionA case of convention and visitors bureaus. Tourism and Hospitality Research, 13(3), 149-165.

Lucchetti, R., \& Sterlacchini, A. (2004). The Adoption of ICT among SMEs: Evidence from an Italian Survey. Small Business Economics, 23(2),151-168.

Loukis, E., Arvanitis, S., \& Kyriakou, N. (2017). An empirical investigation of the effects of firm characteristics on the propensity to adopt cloud computing. Information Systems and e-Business Management, 15(4), 963-988.

Meyer, J. (2011). Workforce age and technology adoption in small and medium-sized service firms. Small Business Economics, 37(3), 305-324.https://doi.org/10.1007/s11187-009-9246-y

Naicker, V., \& Van Der Merwe, D.B. (2018), Managers' perception of mobile technology adoption in the Life Insurance industry. Information Technology \& People, 31(2), 507-526. https://doi.org/10.1108/ITP-092016-0212 
OECD (2000). Information Technology Outlook: ICTs, Electronic commerce and the Information Economy, Paris: OECD.

OIT (2017). World Employment and Social Outlook 2017: Sustainable enterprises and jobs: Formal enterprises and decent work. Ginebra: OIT.

Opiyo, R.O., \& K'Akumu, O.A. (2006). ICT Application in the Informal Sector: The Case of the Kariokor Market MSE Cluster in Nairobi. Urban Forum, 17(3), 241-261.

Orlikowski, W. (1992). The Duality of Technology: Rethinking the Concept of Technology in Organizations. Organization Science, 3(3), 398-427.

Peltier, J.W., Zhao, \& Schibrowsky, J.A. (2012). Technology adoption by small businesses: An exploratory study of the interrelationships of owner and environmental factors. International Small Business Journal 30: 406DOI: $10.1177 / 0266242610365512$

Rogers, E. (Ed.) (1995), Diffusion of Innovation. Free Press, New York, NY.

Tornatzky, L.G., \& Fleischer, M. (1990), The Processes of Technological Innovation. Lexington Books, Lexington, MA.

Valdés, E., Castillo, R., \& Duran, J. (2019).Tecnologías de información y teletrabajo; su estado en Colombia. In: García, C. y R., Astudillo (compiladores).Investigaciones en Gestión Empresarial, Ambiental y Competitividad. (pp. 75-100). Cali, Colombia: Editorial Universidad Santiago de Cali.

Venkatesh, V., Morris, M.G., Davis, G.B., \& Davis, F.D. (2003). User acceptance of information technology: Toward a unified view. MIS Quarterly, 27(3), 425-478.

Viollaz, M. (2018). ICT Adoption in Micro and Small Firms: Can Internet Access Improve Labor Productivity? CEDLAS, Working Papers 0223, Universidad Nal de la Plata, https://www.cedlas.econo.unlp.edu.ar/wp/wp-content/uploads/doc_cedlas223.pdf

Windrum, P., \& De Berranger, P. (2003), Factors Affecting the Adoption of Intranets and Extranets by SMES: A UK Study, Research Memorandum 2003-023, Maastricht, MERIT. https://www.merit.unu.edu/publications/rmpdf/2003/rm2003-026.pdf

Youssef, A., Hadhri, W., \& M'Henni, H. (2011). Intra-Firm Diffusion of Innovation: Evidence from Tunisian SMEs Regarding Information and Communication Technologies, Middle East Development Journal, 3(1), 75-97. DOI: 10.1142/S1793812011000338

\section{Figures}




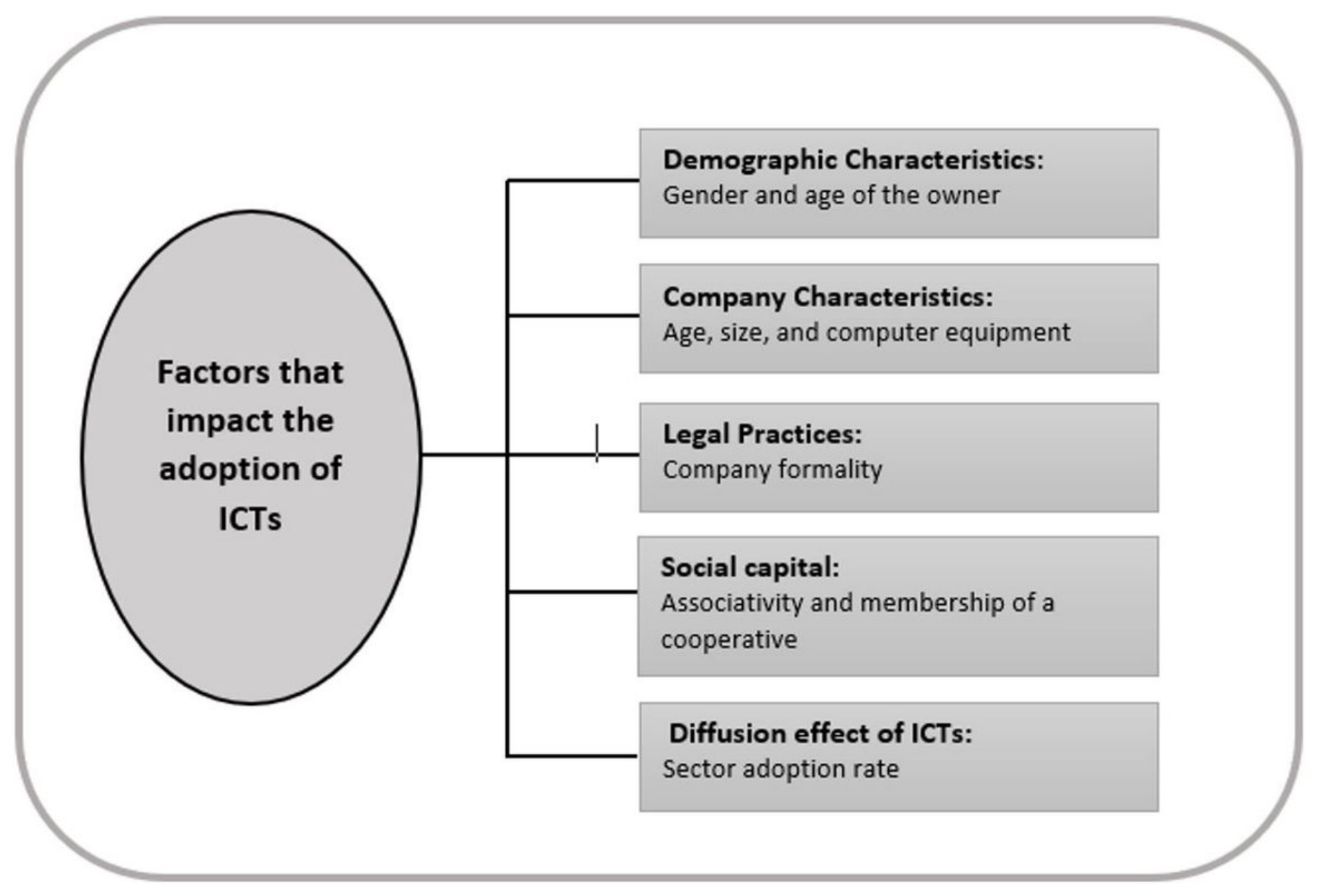

Figure 1

Determinants of ICTs adoption 